\title{
DAS VICISSITUDES DA FALA DA CRIANÇA E DE SUA INVESTIGAÇÃO *
}

\author{
CLÁUDIA THEREZA GUIMARÃES DE LEMOS \\ DL-IEL-UNICAMP \\ Escola de Psicanálise de Campinas
}

Respondo ao convite de Eni Orlandi para dizer da Psicolingüística ou de seu lugar na "História das Idéias Lingüísticas, particularmente no Brasil"1 , neste volume por ela organizado, com o texto que se segue e, a começar, pelo titulo que o anuncia. Nele o que se lê não é nem Psicolingüística nem Aquisição de Linguagem, mas "fala da criança". Nele o que se lê, ao invés de "desenvolvimento lingüístico", é "vicissitudes", termo que significa o que é próprio da "vez" (do latim, vicis), do que, no tempo, toma seu lugar, nele sucedendo seja sob a forma de revezamentos seja sob a dos reveses, referidos aqui tanto às mudanças que a fala da criança pode mostrar quanto às mudanças de posição do investigador ao discerni-las.

É sobre essas mudanças de posição que dizem das vicissitudes da minha relação com a fala da criança que versa este trabalho. Se com ele posso responder a esse convite é, porque, vindo de quem vem, ele me autoriza a colocar-me frente ao que me permite escrever "meu trabalho" ou "nosso trabalho", incluindo o trabalho daqueles que, movidos por suas próprias questões, reconheceram no "meu" um lugar onde alojálas.

Por outro lado, essas mudanças de posição só foram possíveis no interior de um espaço acadêmico onde se podia perguntar, a partir da teoria lingüística, sobre como a criança adquire linguagem, mas onde, por isso mesmo, se pôde deparar com a resistência que a fala da criança opõe ao investigador que dela queira fazer uma empiria a ser descrita pela Lingüística.

À maneira de introdução, eu poderia resumir a história que tais mudanças acabaram por compor recorrendo ao que Eliane Silveira (2000), em referência a meu trabalho, chamou de passos que vão dar em impasses. Impasses que a cada vez refariam e refazem na fala da criança o estatuto de enigma nela reconhecido por Maria Teresa Lemos (1994).

* Este texto é uma releitura do trabalho que venho desenvolvendo desde o doutorado em 1975. Escrevê-lo me oferece a oportunidade de agradecer tanto à FAPESP, que me concedeu essa Bolsa de Doutorado no Exterior por três anos e meio e outras modalidades de auxílio, quanto ao CNPq, do qual tenho recebido a Bolsa de Produtividade em Pesquisa (processo 300989/79-2) desde 1979, pelo apoio recebido.

${ }^{1}$ As aspas sinalizam excerto da carta de Eni Orlandi. 
De fato, se no primeiro passo ${ }^{2}$ o que se interrogava era o conhecimento da língua pela criança e sua fala não passava de direta e inquestionável evidência desse conhecimento, em um dos mais recentes ${ }^{3}$ o que se afirma é a impossibilidade de fazer dessa fala, ou de um corpo que fala, um corpus, isto é, um conjunto de "dados".

\section{OS PRIMEIROS PASSOS, OS PRIMEIROS IMPASSES}

No período da graduação em Letras Clássicas (!952-56, USP), a Lingüística só nos foi apresentada, através de Saussure e Bloomfield, pelo Prof. Theodoro Henrique Maurer Jr. no último ano do curso. O que ficou dessa apresentação foi um ponto de vista que descartava a mudança lingüística em favor da descrição do que em si mesmo era de ordem lingüística.

Passados dezessete anos, muitos dos quais dedicados ao ensino e pontuados por leituras da revista Langages em busca de entendimento do que, na redação dos alunos, aparecia como erros_corpos estranhos_ volto à USP para um curso de Pós-Graduação em Lingüística, ministrado pelo Prof. Isidoro Blikstein, recém chegado de seu doutorado na França. Era um curso sobre Saussure, mas meu interesse pelo erro, visto então à luz do que sobre o patológico (discurso do afásico, do esquisofrênico, do obsessivo) eu tinha lido em um número especial da Langages, levou o Prof. Isidoro a indicar meu nome para substitui-lo no que era então a Cadeira de Lingüística do Curso de Fonoaudiologia da PUC de São Paulo.

Seguiu-se a isso um convite para prestar colaboração ao Instituto Educacional São Paulo, ex-escola privada para crianças surdas doada à PUCSP e que logo depois daria origem ao CERDIC( Centro de Estudo e Reabilitação de Distúrbios da Comunicação, atual DERDIC).

Ali me defrontei não com o erro_ corpo estranho irrompendo em um texto_mas com um estranhamento diante da impossibilidade do texto na escrita de crianças e adolescentes surdos. Já não era possível vislumbrar na diferença, como acontecia com o erro, algo do que se mostrava na mudança lingüística, foco do meu interesse anterior. A pergunta agora era "Que língua é essa?" ou "Isso é uma língua?" As tentativas de intervir nesse estado de coisas a partir de uma certa relação com o que se sabia da Lingüística _ elaboração de roteiro para avaliação de linguagem, introdução de certas práticas e remoção de outras_foram vãs. Baseadas na crença de que a descrição seria o encontro com a verdade do que é lingüístico, não haveria mesmo como lidar com o que a essa descrição escapa. ${ }^{4}$

${ }^{2}$ Como se verá mais adiante, esse primeiro passo é minha tese de doutorado, defendida em 1975 e publicada em 1987 (cf. Referências Bibliográficas).

${ }^{3}$ Refiro-me a Corpo e Corpus, apresentado na I Jornada Corpo e Linguagem, realizada em novembro de 2000, no IEL, UNICAMP e a ser publicado na coletânea dos textos apresentados nesse evento.

${ }^{4}$ Uma discussão sobre a questão do patológico na linguagem se encontra hoje, ampliada e aprofundada, nos trabalhos de Lier-de Vitto, assim como no de suas colaboradoras (Andrade, Arantes e Fonseca, entre outras). (cf. Referências bibliográficas). 
Foi nessa altura, por volta de 1970, que, a partir da leitura dos primeiros livros de Chomsky, decidi estudar Aquisição de Linguagem. Tema e disciplina que, naquele momento, saltavam dos livros de Chomsky para as universidades e centros de pesquisa americanos e ingleses, então voltados para estudos longitudinais da fala da criança periodicamente gravada para esse fim.

Visto com os olhos de hoje, o objetivo que sustentava essa decisão era muito ingênuo: fazer uma tese de doutorado sobre a aquisição do Português Brasileiro a fim de estabelecer parâmetros de normalidade que servissem à avaliação de produções tratadas como patológicas. Por isso parti para Edimburgo em julho de 1971 levando na bagagem as primeiras fitas de gravação da fala de dois meninos a partir de seu segundo ano de vida 5 .

Tendo como tutor e, depois como orientador, o Prof. John Lyons, além de cursar disciplinas que iam do estruturalismo europeu ao americano, da gramática gerativa à semântica formal, participei das atividades do Projeto "Linguistic Development in Children", coordenado pelo próprio Lyons e que contava com pesquisadores como Renira Huxley, Martin Atkinson e Patrick Grifiths.

Ter convivido com a posição sistematicamente crítica assumida por esse grupo relativamente a qualquer teoria, ter participado de longas discussões sobre a acuidade da transcrição de um único enunciado de criança, assim como sobre a validade de uma determinada interpretação-descrição, foi um primeiro contacto com a necessidade de se escapar à naturalização da fala da criança ${ }^{6}$. Isto é, para deter o movimento adaptativo com que o investigador tende a recobrir a diferença_suposição que sustenta o próprio objetivo da investigação_a ela sobrepondo uma interpretação ancorada na identificação pela via da semelhança.

Nesses anos 70, como ainda, em grande parte, hoje, o estatuto da fala da criança era o de evidência de um conhecimento sobre a língua a que estaria exposta, conhecimento esse detido pela teoria lingüística, enquanto teoria sobre todas e cada uma das línguas naturais. Obviamente essa teoria era a teoria gerativa e, na época, também transformacional, que se colocava como objetivo maior não a adequação descritiva mas a adequação explicativa formulada como o problema lógico da aquisição de linguagem pela criança, decorrente da impossibilidade de uma língua possível, isto é, empiricamente não-atualizável, ser aprendida.

É inútil dizer, como disse Chomky em 1964, perante o primeiro grupo de psicolinguistas empenhados em identificar gramáticas infantis com base nas regularidades encontradas na fala da criança, que "the attempt to write a grammar for a child raises all of the unsolved problems of constructing a grammar for adult speech, multiplied by some rather larger factor"(Chomsky 1971: 340) e, mais ainda, que “...it is

\footnotetext{
${ }^{5}$ Maria Cristina da Cunha Pereira e Tai Castilho generosamente se encarregaram desse trabalho.

${ }^{6}$ Representativos dos trabalhos desses pesquisadores naquela época são Atkinson \& Griffiths. 1973, Atkinson, 1974 e Griffiths, 1974 e também Lyons, 1973.

7 Carvalho (no prelo), em cujos trabalhos anteriores (1995 e outros), o foco era o erro, tem-se debruçado sobre essa questão da relação do investigador com a fala da criança, presente já em M.T. Lemos 1994 e outros) questão essa que será retomada mais adiante.
} 
absurd to attempt to construct a grammar that describes observed linguistic behaviour directly." (op. cit.:341 ).

Inútil porque a questão da fala da criança como evidência empírica do conhecimento de sua língua, entendido como distribuído ao longo do tempo ou de uma linha de desenvolvimento_ indo do primitivo para o derivado, do simples para o complexo_ já atingia então a própria teorização do lingüista e sua metodologia. De fato, tanto era necessário dispor de uma descrição lingüística precisa para identificar sua ordem de emergência na fala da criança quanto essa ordem de emergência passava a ser uma evidência a favor ou contra uma determinada descrição da língua em questão.

Em suma: enquanto a relação do lingüista com os fatos linguísticos e com a teoria lingüística era passível de discussão e de mudança, a do investigador com a fala da criança na área da aquisição de linguagem era imediata isto é, não mediada e literalmente indiscutível. Nem é preciso dizer que o que esse investigador acabava por descrever era a atividade lingüística por ele próprio exercida na compreensão dessa mesma fala,

Se essa relação de mão dupla foi mais visível no que diz respeito à hierarquia entre componentes _o que vem antes, a semântica ou a sintaxe ${ }^{8}$ _ houve quem afirmasse a superioridade de sua análise invocando a presença de um determinado constituinte, construção ou expressão na fala inicial da criança ${ }^{9}$

Esse era o estado da arte quando iniciei minha tese. Seguindo a sugestão de Lyons, escolhi um aspecto da predicação do Português que carecia de descrição lingüística mais recente_a oposição entre ser e estar em sentenças locativas_e que, ao mesmo tempo, se inseria na temática em voga no Departamento, dado o trabalho de John Lyons (1975) sobre dêixis e o de John Anderson (1971) sobre aspecto na Gramática de Caso Localista. $\mathrm{O}$ fato de ter chegado à formalização do que tratei como caráter aspectual da oposição entre as cópulas, através de predicados atômicos, à maneira de Dowty (1972) e de Atkinson (1974) não me serviu de mediação teórica para chegar à fala da criança.

Em primeiro lugar, porque as ocorrências de ser e estar eram de freqüência e distribuição muito limitadas até os dois anos, o que me obrigou a tratar do que chamei de manifestações aspectuais, contando desde monossílabos como bô, interpretados como acabou/quebrou, até "formas verbais com flexão" para fazer algum sentido enunciável em uma tese de doutorado.

Em segundo lugar, porque, em vez de regularidades, encontrei a heterogeneidade sob a forma de fragmentos do enunciado precedentes do adulto, restos de expressões usadas pelo adulto em determinadas situações, "flexões" que, na verdade só ocorriam com um deteminado verbo, enfim algo que resistia à sistematização. Ainda assim, a

${ }^{8}$ É interessante notar que o recurso de ordenar componentes_semântica, sintaxe ou pragmática, semãntica, sintaxe _ para escapar à impossibilidade de reconhecer uma sintaxe na fala inicial, comum nos anos 70, retorna hoje na linha gerativista de pesquisa sob a expressão pre-functional stage (Radford 1990), a ser lida como "estágio pré-sintatico" e até sob o têrmo bootstrapping. (Pinker 1987, entre outros) que atribui a uma semântica (ingenuamente concebida) a tarefa de colocar a criança ou a GU face ao sintático atualizado no input.

${ }^{9}$ Cf., por exemplo, Gruber (1967) e H.H. Clark (1973) 
mudança estava ali na fala da criança, na eficácia que ela aparentava ganhar através da interpretação do adulto, na maior extensão dos enunciados e em seu contínuo deslocamento para outras situações. Se a tese se tornou apenas um lugar de encobrir o impasse com uma leitura pendendo para o cognitivismo, foi esse mesmo impasse que determinou o passo seguinte.

\section{OS PROCESSOS DIÁLOGICOS}

Já no Brasil e no Departamento de Lingüística da UNICAMP, o passo dado foi o Projeto de Aquisição de Linguagem que deveria prover o que se julgava insuficiente: mais fala de criança, mais crianças, mais pesquisadores. Com o auxílio da FAPESP foi possível obter equipamento e material de consumo para gravar semanalmente, sempre que possível, cinco crianças, da idade de um ano até a de cinco, em interação com a mãe, outros membros da família e uma ou duas das investigadoras

Se o impasse, ao terminar a tese, se configurava como impossibilidade não só de depreender dos dados uma ordem de emergência compatível com alguma proposta lingüística mas principalmente de "regularizar" o heterogêneo para chegar a uma descrição, o passo que se dava com a criação do Projeto mostrava a presença dominante da Psicologia na Aquisição de Linguagem da época.

Primeiro, porque se acatava a suspeita que os métodos da Psicologia faziam recair sobre estudos não experimentais, elevando o número de crianças e de dados longitudinais a seu limite. Segundo, porque, se não era possível submeter a Lingüística à Psicologia do Desenvolvimento pela definição de ordens de emergência ou de estágios, a solução que se apresentava era colocar o desenvolvimento lingüístico como subordinado e consequente a um desenvolvimento cognitivo e/ou comunicativo precedente. É significativo, nesse sentido, que o título do Projeto, implementado em 1976, era "Relações entre desenvolvimento lingüístico, desenvolvimento cognitivo e desenvolvimento comunicativo", colado, assim, a tudo o que fazia na época ${ }^{10}$.

Em contraponto a esse distanciamento do lingüístico se levantavam duas barreiras. Primeiro, o fato de a questão que inspirou o Projeto_a fala da criança e o quantum de lingüístico se podia e se devia atribuir a ela_ter-se mantido como eixo da interpretação e do desejo de teorização. Segundo, o fato de as pesquisadoras que nele se engajaram, em seu percurso de doutorado, serem ou lingüístas efetivamente voltadas para o lingüístico, como Ester Scarpa, Maria Cecília Perroni e Rosa Attíe Figueira, ou _ é o caso de Maria Fausta Pereira de Castro_ uma psicóloga realmente interessada em linguagem.

Por isso mesmo, o que emerge desse primeiro momento do meu trabalho com os dados do Projeto é a noção de processos dialógicos que visava a dar um estatuto, pelo menos descritivo, à congruência entre a fala da criança pequena e a de seu interlocutor

${ }^{10} \mathrm{Ou}$ a exemplo de projetos como o do Istituto de Psicologia do CNR, de Roma, de que participavam Elizabeth Bates, Luigia Camaioni, Virginia Volterra e Francesco Antinucci, e do Departamento de Psicologia da Universidade de Oxford, coordenado por Jerome Bruner, projetos com os quais mantivemos relações estreitas até meados dos anos 80 . 
adulto que esses dados mostravam. Ou melhor, à aparente coesão e progressão dialógicas que emergiam como efeito tanto do enunciado com que o adulto interpretava o que a criança fazia ou falava de modo ainda informe e fragmentado, quanto pela dependência que essa fala fragmentada mostrava ao se ancorar na fala do adulto, muito particularmente na fala da mãe. Por isso mesmo, mais que aos aspectos pragmáticos dessa interação, aquilo a que se queria dar estatuto era à conexão de natureza lingüística que essa interação tão desigual produzia.

No trabalho em que pela primeira vez se define essa noção (de Lemos, (1981[1979]), a justificação oferecida era metodológica: se a noção de desenvolvimento exigia que se recuperasse a continuidade entre a comunicação adultocriança no período então chamado de pré-lingüístico e a chamada fala inicial, o diálogo _ e não o enunciado isolado da criança_ era a unidade de análise que satisfaria esse requisito.

Diálogos como:

Episódio 1 (Terminada a refeição, L. sentado no cadeirão, dá "mostras" de impaciência.)

M. Quer descer?

L. qué

M. Você quer descer?

L. decê

$$
(\mathrm{L}: 1 ; 7)^{11}
$$

Episódio 2 ( L.está sentado no chão com brinquedos.)

M. Você vai brincar?

L.: hum

M. Hum?

L. intá

M. Do que você vai brincar?

L.: nenê/nenê

M. Nenê, ahm?

L.: nenê intá

M.: Nenê vai bintá?

L.: é/nenê bintá

permitem apontar para o que então era interpretado como "processos constitutivos do diálogo e da aquisição de linguagem”(de Lemos 1985[1981]). Primeiro, para o processo chamado de especularidade, definido como presença na fala da criança de parte do enunciado da mãe que o antecede, assim como pela incorporação da fala da criança no enunciado da mãe. Segundo, para o processo de complementaridade,

${ }^{11}$ A convenção utilizada nos estudos de aquisição de linguagem com respeito à idade da criança é a seguinte: número de anos seguido de ponto-e-vírgula, número de meses seguido de ponto simples e número de dias. 
representado pela relação da pergunta da mãe com a resposta da criança e, principalmente, pela relação formal entre as partes mutuamente incorporadas que parecem completar-se, compondo uma unidade ou instanciando uma "sentença". Terceiro, pelo processo de reciprocidade, definido como retomada pela criança do papel da mãe, iniciando a interação, desencadeando com sua fala uma fala que refletiria e completaria a sua.

Ao nomear esses processos, retomavam-se os têrmos usados por Camaioni ( 1978, entre outros) para designar as interações, consideradas sob seu aspecto não-verbal, entre criança-criança e adulto-criança. Supunha-se assim garantir tanto uma ancoragem na literatura quanto a continuidade entre o "pré-lingüístico" e o lingüístico.

Essa suposição durou pouco. Já no segundo artigo sobre o tema, o processo de especularidade toma outros rumos, reduzindo os outros a efeitos secundários. Isso porque, de um lado, do ponto de vista "empírico", a complementaridade se dava através da especularidade: nenê que, no episódio 2, vem "complementar" intá, que vem do enunciado da mãe e reaparece na composição nenê intá/nenê bintá, não deixa de ser um retorno da fala da mãe na fala da criança, isto é, uma instância do que foi chamado de especularidade não imediata ou diferida. Esse também é o caso do processo de reciprocidade, ilustrado no mesmo artigo pela recorrência de decê em iniciativas da criança para sair do cadeirão em episódios posteriores a 1 (cf. op. cit.: 24-25).

Por outro lado, o têrmo "especularidade", escolhido por Camaioni para escapar à pecha de behaviorista ${ }^{12}$ que na época incidia sobre o têrmo "imitação", fez valer o espelho a que, na verdade, se referia. Espelho ou espelhamento que punha em questão o comunicativo cuja continuidade se queria preservar e o lingüístico enquanto conhecimento instanciado na fala da criança.

Visto com os olhos de hoje_ou de um lugar outro desde o qual o que foi ganha outro sentido_e através de lentes como o trabalho de M.T. Lemos (1994) e, mais recentemente, o de Arantes (2000)_o processo de especularidade diz das vicissitudes de um conceito.

Diante da imitação como fenômeno só poucos dentre os pesquisadores que se colocaram diante da fala inicial da criança puderam fechar os olhos. O que se fez desse encontro forçado em torno dos anos 70 , contudo, releva do desafio que a aquisição da sintaxe representava como efeito da proposta chomskiana.

Houve os que ignoraram o desafio, restringindo-se a tomar a imitação recíproca como prova de que o comunicativo precedia e determinava o lingüístico no desenvolvimento da criança (cf., entre muitos outros, Snow 1972). Outros, em contraponto, empenharam-se na discussão da imitação como processo que conduziria à sintaxe.

No segundo caso, saliento, por sua relevância para meu próprio trabalho, o artigo de Brown \& Bellugi (1971[1968]) e a série de trabalhos de Ruth Clark (1974, 1975, 1977 entre outros.).

${ }^{12}$ Sobre o discrédito do behaviorismo que sobreveio à resenha de Chomky (1967) sobre o livro Verbal Behaviour de Skinner (1957), ver Faria (2001). 
Brown \& Bellugi (op. cit.), com efeito, dão reconhecimento à imitação_ com redução_da fala do adulto pela criança, assim como da imitação da criança pelo adulto. Chamam atenção ainda para o fato de o adulto retomar o enunciado reduzido da criança, expandindo-o ou preenchendo suas lacunas. Imitação e expansão são tratados, portanto, como processos operativos na aquisição da sintaxe. A esses dois processos, porém, é acrescentado um terceiro_ "a indução da estrutura latente" de sentenças: o único, segundo os autores, efetivamente responsável pela sintaxe e que, segundo a análise por eles efetuada, emerge da busca pela criança das regularidades de sua língua. Isto é, um processo indutivo que é curiosamente associado pelos autores `a posição chomskiana, já que qualificado como "more reminiscent of the biological development of an embryo than it is of the acquisition of a conditioned reflex" (op. cit.: 318). São assim eliminados imitação e expansão.

Esse não é o caso de Ruth Clark (op. cit.) para quem a imitação vai além da fala inicial em que é indicativa da apreensão idiossincrática, pela criança, da forma e do sentido do enunciado imitado do adulto. Para a autora, segmentos que, por imitação diferida, são armazenados na memória de longo têrmo, constituem o material lingüístico sobre o qual a criança vai operar tanto para produzir enunciados mais complexos, através de estratégias como o acoplamento ou o amálgama de diferentes segmentos, quanto para deles extrair informação gramatical e semântica.

Cabe dizer que o empenho de Ruth Clark em compor um modelo em que a imitação é central, ao mesmo tempo que lhe permitia lidar com enunciados em que a fala da criança faz ver toda a sua diferença, não a levou a pôr em dúvida nem a criança como sujeito do conhecimento nem a linguagem como objeto de conhecimento. Prova disso é que R. Clark explica diferença e estratégias como resultantes da insuficiência da criança relativamente ao processamento da fala e à apreensão de conceitos nela expressos, assim como aos limites de sua memória de curto e longo têrmo.

Interessante é notar que essa reflexão_de que R. Clark abdicou para se dedicar a outra coisa_ reaparece simplificada na literatura sobre processos reorganizacionais, principalmente em Peters (1977), que elimina o que o têrmo imitação teria de subversivo e o substitui por extração. Isto é, descarta a relação da criança com a fala da mãe e sua relevância como base de sustentação de um diálogo inicial possível, em favor de um mecanismo perceptual que extrai do input porções de maior saliência perceptual e/ou referencial (associável a objeto presente no contexto). O material extraído_e armazenado na memória de longo têrmo_é, então, utilizado na indução de segmentos e de sua posição em estruturas, operação a partir da qual se constituiriam unidades lexicais e classes morfológicas.

Se tomei um outro caminho, a indicação me foi dada pelo têrmo especularidade e pelo encontro com Baldwin (1899) em um texto de Piaget (1928:168) que, referindo-se à imitação recíproca segundo esse autor, assim a definia: “...l'imitation réciproque, c'est à dire précisement, la réflexion (au sens propre) de soi en autrui et d'autrui en soi". O próprio Piaget, no mesmo texto, estende os efeitos desse espelhamento, perguntando-se sobre sua função na "objectivation de son (da criança) univers" (1928: 198).

O que de subversivo havia na especularidade/espelhamento estava na dúvida que lançava sobre a criança enquanto indivíduo já constituído para aprender/adquirir 
linguagem e sobre o lugar que cabia ao outro e à sua fala na fala da criança e no próprio processo de aquisição de linguagem. Interrogar-se sobre quem fala na fala da criança implicava a suspensão de critérios estritamente lingüísticos para a suposta análise da fala da criança e, no limite, a impossibilidade de descrição do conhecimento lingüístico de que essa fala seria evidência.

Uma saída precária desse impasse foi tratar esses enunciados iniciais como lingüisticamente indeterminados, indeterminação essa que incidia até mesmo sobre sua função comunicativa: quem fala e a quem (se) fala? Precária porque anunciava, sob a forma de uma falta que viria a ser preenchida, um momento em que a criança assumiria um discurso próprio e determinável, enquanto instanciação de um conhecimento lingüístico passível de descrição. Mantinha-se assim a língua como objeto de conhecimento e a relação com o outro materno como relação dual, provedora de fala, porém, não atravessada pela língua enquanto terceiro.

$\mathrm{O}$ que veio à tona nos trabalhos dos outros membros do projeto, por um lado, confirmava a incorporação da fala do outro pela criança, quer no nível prosódico de realização dos processos dialógicos, estudado por Ester Scarpa (1984), quer nos "casos" de Maria Cecília Perroni ([1984] 1992), enquanto relatos tecidos com fragmentos de histórias contadas pela mãe, quer nas estruturas argumentativas, objeto da investigação de Maria Fausta Pereira de Castro (1992 [1986]). Por outro lado, através deles também se dava a ver a incongruência e discrepância na fala da criança.

A atualização de uma estrutura_prosódica, sentencial, textual_que abria lugares preenchidos de forma aparentemente aleatória dava lugar a "erros" que advinham da migração dos fragmentos incorporados de uma para outra cadeia, de um para outro texto.

Foram, contudo, "erros" de natureza estritamente lingüística, resultantes da substituição de verbos causativos por incoativos e vice-versa_objeto específico da investigação de Rosa Attiê Figueira (1986)_ que mostraram uma possível porta de saída da relação dual em que os processos dialógicos pareciam detidos.

Em 1982, em um artigo intitulado "Aquisição de linguagem: seu dilema (pecado) original “, abordo o "erro" como indício de mudança e, portanto de desenvolvimento, visto sinalizar a saída da indeterminação e do total submetimento à fala do outro. Nesse sentido, o "êrro" também se apresentava como possibilidade de escapar do "dilema (pecado) original" a que estava atado o investigador que, não vendo alternativa à descrição categorial dos enunciados da criança, estava impedido de atender à diacronia do processo de aquisição de linguagem, sobrepondo, através dessa descrição, os pontos de partida e de chegada. Ao interpretar erros como o uso de apagar por acender, ou a sufixação bizarra da expressão vai lá! em vailô!, pude chamar a atenção tanto para um distanciamento da fala do adulto quanto para o que denominei, naquele momento, processo de organização de procedimentos que, anteriormente isolados ou justapostos, passavam a entrar em relação. Tais relações, ainda que supostamente direcionadas à formação de classes e/ou categorias, estavam ainda a meio caminho do saber lingüístico suposto ao adulto. Que conhecimento, então, atribuir a essa criança que erra entre o erro e o acêrto? 
Ancorada no efeito que a fala inicial da criança tinha sobre o adulto assim como sobre o que se nomeava conhecimento do mundo, termino esse artigo dizendo:

"Ainda que incompletas, essas considerações finais me levam a concluir que é através da linguagem enquanto Ação sobre o Outro (ou procedimento comunicativo) e enquanto Ação sobre o Mundo (ou procedimento cognitivo) que a criança constrói a linguagem enquanto Objeto sobre o qual vai poder operar." (op.cit.:13)

Esse parágrafo diz menos do dilema da aquisição de linguagem que de minha impossibilidade de dar reconhecimento à função do outro e, ao mesmo tempo, à língua/linguagem enquanto Outro. Daí o meu apelo ao "sujeito ativo" da psicologia, situado entre o piagetiano e o vygotskiano, para o qual outro, mundo e linguagem se dão como objetos a serem "construídos". Um apelo surdo às questões levantadas pelo processo de especularidade.

A oscilação entre o outro e a língua_ cernidos mais no que a fala da criança fazia ver deles do que por um olhar instrumentado por teorias ${ }^{13}$ - se faz sentir nos vários artigos que escrevi até 1992 (ver, principalmente, 1984 e 1986) momento em que encontro na Psicanálise, mais precisamente, em um primeiro contato com a obra de Jacques Lacan, razões tanto para insistir na Lingüística como para um afastamento crítico em relação à Psicologia do Desenvolvimento.

\section{OS PROCESSOS METAFÓRICOS E METONÍMICOS}

Em que a posição que eu tentava sustentar diferia, mais precisamente, daquela dos psicólogos socio-construtivistas que colocavam em relação processos intersubjetivos e linguagem? Essa foi a questão que desencadeou a mudança de rumo anunciada por um trabalho publicado em 1992 _ "Los procesos metafóricos y metonímicos como mecanismos de cambio"14, que começa pela discussão da posição de Bruner (1975 e outros) e, principalmente, da de Vygotskii (1978[1930]).

Tomando-se Vygotskii como referência básica das propostas socio-construtivistas, é possível defini-las pelo objetivo visado. A saber: dar conta da construção do sujeito humano, enquanto sujeito do conhecimento, a partir de seu ser biológico e de sua transformação em ser histórico-cultural, através da elaboração dos processos de transmissão da ordem cultural, ancorados tanto no adulto quanto na linguagem. $\mathrm{O}$

${ }^{13}$ Viviane Veras (2000: 122 ) refere-se a meu trabalho, dizendo: “A fala da criança é um desafio para o trabalho de Cláudia de Lemos; mais que um desafio, eu diria que é aquilo que o causa". Ao que acrescenta, em nota de rodapé: "Causa, na função que lhe dá Jacques Lacan, no Seminário XI, como intervalo entre ação e reação_ não há causa senão do que falha (Cf. Les quatre concepts fundamentaux de la psychanalyse, Paris: Points, 1964, pp. 30-1)". O efeito que suas palavras tiveram sobre esta reflexão fica registrado aqui.

${ }^{14}$ Esse trabalho foi apresentado em inglês em um Simpósio Internacional sobre Mecanismos de Mudança, organizado pela Universidade de Barcelona, em 1991 e, posteriormente, vertido para o espanhol para ser publicado, com os demais trabalhos apresentados, no primeiro número da revista Substratum. Quero registrar aqui que essa versão em espanhol contém erros graves, incidindo sobre pontos cruciais do que foi proposto. 
primeiro, em seu estatuto de mediação necessária na relação sujeito- objeto; a segunda enquanto instrumento que serve à natureza conceitual dessa relação.

A transformação qualitativa resultante da relação criança-adulto se definiria, então, pela transformação de processos intersubjetivos em processos intra-subjetivos. Uma outra transfomação qualitativa, mediada pelo primeira, adviria da operação com signos, concebido o signo enquanto um terceiro elemento que quebraria o vínculo natural entre a criança/sujeito e mundo/objeto, abrindo o caminho para a abstração do conceito (ver, a propósito, Lier-de Vitto (1998[1994]).

Se na primeira ordem de transformações a fala do adulto dirigida à criança é o motor da operação a ser interiorizada_intra-subjetiva_, a segunda diz respeito à língua/linguagem. Mas, como, através do adulto e de sua fala, a criança teria acesso à língua/linguagem, já que esta, ainda que reduzida a signos e abordada pelo viés do significado, colocava em cena a materialidade significante como um terceiro? Enfim, o que daria à substância fonética _ aos sons da fala do adulto_o estatuto simbólico que implicaria a significação, quebrando o vínculo supostamente natural da criança com os sons da fala enquanto substância? Ou ainda: o que, do outro ou de sua fala, mediaria o acesso da criança ao que na língua se furta à percepção, à apreensão imediata pelos sentidos?

Com os olhos de hoje, reconheço quanto essa questão afetava meu próprio trabalho, ainda que nele não compareça o conceito de mediação nem uma concepção de língua centrada no signo. Se a aquisição de linguagem, de qualquer perspectiva teóricoepistemológica, implica mudanças, como proceder diante do mistério que envolve seu ponto de partida?

Uma saída é vislumbrada no encontro com o que na obra de Lacan (1998 [1966]) remete a um Saussure que a Lingüística tinha descartado, aquele que tentou apreender as propriedades mínimas da língua, situadas aquém do que se trata como evidente: unidades, classes e categorias. É o que diz Milner sobre o pensamento de Saussure por ele qualificado de "tentativa que permanece surpreendente e admirável. Ela obriga os linguistas a não tomar nada como evidente" (2002: 143).

Determinada pela fala do outro, indeterminada do ponto de vista categorial, heterogênea, resistente à depreensão de suas regularidades e de seus pontos de mudança, assim se mostrava a fala da criança diante de minha tentativa de apreendê-la como evidência de conhecimento da língua.

A despeito disso tudo, havia algo a dizer da língua nessa fala, algo que tomou uma forma primeira através de uma releitura de Saussure em que se privilegiou a teoria do valor, o conceito de sistema como sistema de relações_e não de unidades_regidas pela pura diferença. Enfim, algo sobre o funcionamento da língua na fala inicial ou sobre as relações entre os fragmentos da fala da criança e os enunciados da mãe; algo sobre o funcionamento da língua revelado pelos "erros" enquanto produtos de relações entre cadeias que se cruzam produzindo substituições.

Essa possibilidade de dizer algo sobre um movimento que poderia dar lugar à mudança se concretizou, porém, na releitura do admirável texto de Jakobson (1963[1956]) sobre os processos metafóricos e metonímicos, em que as relações associativas e as relações sintagmáticas de Saussure eram reinterpretadas a partir das 
figuras de linguagem_ a metáfora e a metonímia_ tidas como sua "expressão mais condensada" (op. cit.: 61).

Esses processos, definidos o primeiro pela substituição, em uma estrutura, de um têrmo por outro, e o segundo pela combinação ou contigüidade na relação de um têrmo a outro, ao serem nomeados como "metafóricos" e "metonímicos", remetiam ao efeito da substituição e da combinação/contigüidade, isto é, à produção de um terceiro (cf. Milner 1989: 390-391).

Na medida em que mantinham o que, em Saussure, tem o estatuto de propriedades mínimas e, ao mesmo tempo, apontavam para um efeito para além dessas propriedades, tais processos permitiriam apreender, a meu ver e como queria Jakobson, a linguagem em seu estado nascente na fala da criança, assim como o movimento que produziria a mudança.

Os episódios que analisei nesse trabalho (e que continuo reanalisando até hoje) são aqui trazidos para tornar mais claro o que, então, sustentava a proposta expressa no próprio título do artigo em espanhol: Los procesos metafóricos y metonímicos como mecanismos de cambio.

\section{Episódio 3:}

(M. entrega para a mãe uma revista tipo Veja)

M.: ó nenê/o auau

Mãe: Auau? Vamo achá o auau? Ó, a moça tá tomando banho.

\section{M.: ava? eva?}

Mãe: É. Tá lavando o cabelo. Acho que essa revista não tem auau nenhum.

\section{M.: auau}

Mãe.:Só tem moça, carro, telefone.

M.: Alô?

Mãe.: Alô, quem fala? É a Mariana?

(Mariana 1;2.15)

Seria a relação de contigüidade que teceria o diálogo criança-mãe no episódio 3, mostrando assim a dominância do processo metonímico na fala inicial. Como se pode inferir desse diálogo, ó nenêlo auau é um fragmento do discurso da mãe em situações de "ler"/mostrar figuras em revistas, fragmento que se desprende de um texto para pôr em cena (mise-em-scène) a situação/cena anterior. Do mesmo modo, os fragmentos (1)ava?/eva?, são convocados pela expressão tomando banho presente na fala da mãe, expressão que, tomada como parte de um texto tomado como todo, o torna presente através de uma outra parte/ fragmento, (l)ava. Essa interpretação se estenderia à relação entre telefone, no enunciado da mãe, e alô, no enunciado da criança.

Já no episódio 4 abaixo, é a dominância do processo metafórico que se dá a ver naquilo que se apresenta à primeira vista como "êrro". 


\title{
Episódio 4:
}

(Quando M. faz muito barulho, a mãe a repreende dizendo que ela vai acordar a vizinha, Flávia, que está dormindo. Durante este episódio, C. brinca com uma bola.)

Mãe: Esta bola faz muito barulho.

M.: A Fávia é nananda.

Mãe : É, a Flávia está nanando e você fica fazendo barulho.

(Mariana: 1;9.15)

Se o processo metonímico se mostra no diálogo acima através da relação entre barulho no enunciado da mãe e o enunciado da criança $A$ Fávia é nananda, parte do texto em que a mãe chama a atenção da criança para o efeito do barulho que ela faz, é o "êrro" nele contido que dá a ver o vestígio de um processo metafórico assinalando um afastamento do enunciado da mãe.

Com efeito, a substituição de está por é, assim como a de nanando por nananda, traz à tona a relação entre o forma do presente progressivo está nanando e predicações nominais como é bonito/é bonita, está bonito/está bonita, em que ser e estar estão em oposição e em que é requerida a concordância do predicativo com o sujeito.

Seria possível, então, atribuir uma natureza metafórica à relação entre o têrmo substituído e o têrmo latente, entre o que chamei de cadeia manifesta e cadeias latentes $^{15}$, na medida em que essa relação produz um terceiro, a saber, a ressignificação desses têrmos enquanto associados em uma classe definida por uma propriedade estrutural ? Foi com base nessa reflexão que, no artigo em pauta, tento explicitar como o processo metafórico, em particular, desencadeia a mudança:

\begin{abstract}
"[...] creio que essa ressignificação introduz um efeito de assemelhamento que é um primeiro passo na incorporação de auxiliares e copulativos em uma classe mais ampla e em torno de uma propriedade comum. Considerando que o efeito de assemelhamento implica a emergência de diferenças, pode-se fazer a hipótese de que um processo de ressignificações sucessivas seja responsável pela sub-categorização dessa classe em auxiliares e copulativos e, portanto, igualmente responsável pelas restrições impostas às operações de substituição em estruturas".

Certos fatos da mudança lingüística nas línguas mostram a plausibilidade dessa hipótese.

Um deles é o processo pelo qual habere, verbo que em latim significava "agarrar", passa a integrar estruturas possessivas com o particípio passado como objeto direto, sofrendo um processo de ressignificação até vir a desempenhar funções de auxiliar nas línguas românicas.[...].” (de Lemos 1992 : 132)
\end{abstract}

Os parágrafos acima dão a ver quão resistente era, no meu trabalho, um modo de conceber a mudança como um processo de desenvolvimento governado pela miragem de um estado final, ponto de cessação do movimento, lugar de um saber que não poderia senão espelhar o que uma outra Lingüística_a que o estruturalismo de Saussure e mesmo de Jakobson era antinômico_tinha a dizer sobre a língua e a linguagem.

15 "Conteúdo manifesto" e conteúdo latente" são os têrmos usados por Freud (1976[1900]) para descrever o trabalho do sonho, isto é, a condensação e o deslocamento que Lacan ( 1998[1953]] viria a interpretar como processos metafóricos e metonímicos. 
Ao qualificar a trajetória da criança pela língua como a passagem de interpretado pelo outro a intérprete, também a interpretação ficava reduzida a esse saber, ainda que, em 1991, em um texto intitulado "Saber a língua e o saber da língua" esse saber tivesse sido questionado.

Mais um impasse, portanto, configurado também por uma impossibilidade de ordem empírica: a heterogeneidade e imprevisibilidade dos "erros" e, em particular, o confronto com "erros" em que cadeias manifestas e cadeias latentes remetiam à homonímia ou ao equívoco, isto é, ao fato de uma expressão poder ser, ao mesmo tempo, ela mesma e uma outra, e não a uma uma substituição autorizada, de certa forma, por uma posição na estrutura.

É o caso dos "erros" que vêm sendo estudados por Carvalho (1995 e a sair, entre outros) e por ela significativamente nomeados de "erros de não-saber": enunciados como deceu vedi, cujo acontecimento a autora qualifica como equívoco associável à insistência, nos diálogos entre a criança e a mãe, de expressões como deixa eu verldeichovê, e assim como de verde/vedi em episódios em que se identificam cores de objetos (Carvalho, a sair).

\section{DA ORDEM PRÓPRIA DA LÍNGUA A UM VISÃO ESTRUTURAL DA MUDANÇA $^{16}$}

O passo que responde a esse impasse se anuncia quase como uma retirada. Deixando um pouco de lado a fala da criança, volto-me, de 1992 a 1997, de novo para Saussure (cf. de Lemos 1995a e 1995b) e Jakobson (1963 e 1998a), assim para uma leitura mais detida de Chomsky (cf. de Lemos 1998b), à procura de uma definição mais clara do sujeito que seria compatível com a concepção de língua na teorização da Lingüística.

Cabe, porém, dizer que esse passo responde ao efeito que teve sobre meu trabalho o ter-me dado conta, através de uma relação então mais estreita com a obra de Jacques Lacan, de que os processos metafóricos e metonímicos não remetiam a um movimento autônomo da língua sobre si mesma, mas sim a um sujeito, isto é, ao modo de emergência do sujeito na cadeia significante. Estava, portanto, também em questão nesse momento, a possibilidade de uma relação entre Lingüística e Psicanálise no campo da Aquisição de Linguagem.

$\mathrm{O}$ fato de que aquilo que Saussure nomeou ordem própria da língua estar na origem dos dois projetos de constituição de uma Lingüística científica, a saber, tanto no projeto estruturalista representado pela obra do próprio Saussure quanto no projeto gerativista representado, em seus fundamentos, pela obra de Chomsky, foi, então, tomado como pivô dessa reflexão.

Dela, melhor dizendo, da radical alteridade da língua relativamente ao humano concebido como organismo que se apropria de objetos de conhecimento, decorre o que

${ }^{16}$ Esta seção e as que a ela se seguem, com exclusão apenas da última, foram adaptadas do Relatório Científico enviado ao $\mathrm{CNPq}$, correspondente às atividades desenvolvidas de março de 1997 a março de 1999, período de vigência de Bolsa de Produtividade em Pesquisa. 
Chomsky, a partir de 1965, formula como o problema lógico da aquisição de linguagem. A saber, dada essa radical alteridade, traduzida por ele em termos de uma não-observabilidade das propriedades linguiísticas e de uma consequente impossibilidade delas serem apre(e)ndidas por generalização indutiva, que criança é essa que adquire a linguagem ? Ou melhor, que sujeito está em questão?

$\mathrm{O}$ fato de que a hipótese por ele levantada em resposta a esse problema lógico tenha sido a de colocar na criança, enquanto indivíduo da espécie, e especificamente em sua mente/cérebro, um conhecimento prévio sobre a língua_conceituada como língua possível_não diminui a relevância teórica do problema.

Com efeito, se dessa concepção de língua decorre a impossibilidade de sua aprendizagem, de sua natureza enquanto sistema também decorre a impossibilidade de submetê-la a uma série ordenada de apreensões parciais, como implicado pela noção de desenvolvimento.

Foi esse mesmo problema que_insisto em afirmar_ decorre do projeto estruturalista de Saussure, norteou minha busca, ainda que em sentido contrário à solução proposta em Chomsky. Note-se que na solução chomskiana mantém-se a relação sujeito-objeto, já que para garantir o acesso a uma língua particular, projetamse as propriedades das línguas possíveis (em 1965, os universais substantivos e formais, na teoria de Princípios e Parâmetros, a Gramática Universal ou GU, cf. Chomsky 1986) na mente/cérebro que, no modelo, tem a função de condição do sujeito epistêmico.

O que a mim pareceu, então, coerente com essa autonomia e alteridade radical da língua foi dar a ela, à língua, a função de captura, entendida como como estenograma ou abreviatura (sobre esse conceito metodológico, ver Milner 1989) de processos de subjetivação. Considerada sua anterioridade lógica relativamente ao sujeito, o precede e, considerada em seu funcionamento simbólico, poder-se-ia inverter a relação sujeitoobjeto, conceber a criança como capturada por um funcionamento lingüísticodiscursivo que não só a significa como lhe permite significar outra coisa, para além do que a significou.

Esse além, que caracterizaria a mudança ou o lado "criativo" desses processos não seria, portanto, assimilável à noção de criatividade em Chomsky (nem à de 1965 nem a reafirmada recentemente, em 1995, como característica de Ss ou estado estável), já que não seria consequente apenas à língua, ou à natureza gerativa da sintaxe.

Essa reflexão se apoiava, do ponto de vista empírico, em fenômenos específicos da fala, isto é, que não concerniam ao estritamente lingüístico do enunciado, mas que compareciam, por assim dizer, como indícios da enunciação. Fenômenos que, com base na psicanálise, remeti à noção de escuta, no sentido em que esta difere do ouvir, enquanto atividade sensorial, de ordem fisiológica.

De fato, uma mudança significativa no modo de a criança estar na língua, reconhecida até mesmo por um inatista radical como Pinker $(1989,1995)$, se dava a ver concomitantemente à produção de "erros": a impermeabilidade da criança à correção do erro pelo adulto. Assim, se o "êrro", do ponto de vista lingüístico, já marcava, na fala da criança, um distanciamento da fala do outro, essa mudança também se dava a 
ver pelo não reconhecimento, pela criança, da diferença entre a sua fala e a fala do outro.

A interpretação desses fenômenos como relevando de uma mudança de posição do sujeito abria também a possibilidade de tratar as hesitações, "correções", tentativas de reformulação pela criança de seu próprio enunciado, presentes em momento cronológico posterior. como indícios de outra mudança de posição isto é, de uma outra relação da criança com sua própria fala e com a fala do outro.

Da conjunção desses argumentos teóricos e empíricos, emergiu, ainda que de forma preliminar naquele momento (cf. de Lemos 1997), a proposta de que as mudanças que qualificam a trajetória da criança de infans a sujeito-falante são mudanças de posição relativamente à fala do outro, à lingua e, em consequência, em relação à sua própria fala.

Foi, em um segundo momento (cf. de Lemos 1999 e 2000) que essa mudança foi definida como mudança de posição em uma estrutura, no sentido em que não há superação de nenhuma das três posições, mas uma relação que se manifesta, na primeira posição, pela dominância da fala do outro, na segunda posição, pela dominância do funcionamento da língua e, na terceira posição, pela dominância da relação do sujeito com sua própria fala.

Seria na terceira posição que a criança, enquanto sujeito falante, se dividiria entre aquele que fala e aquele que escuta sua própria fala, sendo capaz de retomá-la, reformulá-la e reconhecer a diferença entre sua fala e a fala do outro, assim como entre a instância subjetiva que fala e a instância subjetiva que escuta de um lugar outro. Essa interpretação valia, portanto, como contra-argumento à interpretação desses fenômenos_ou dos fenômenos que apontam para essa divisão_ como evidência de capacidades metalingüísticas, justamente a partir da discordância entre essas duas instâncias.

Essa proposta, assentada quer sobre a alteridade radical da língua relativamente ao organismo, quer sobre a consideração daquilo que, na fala da criança, aponta para um sujeito que, ao se constituir na língua, por ela é dividido, representava acima de tudo uma alternativa à noção de desenvolvimento.

Em um certo sentido, ainda que timidamente, essa proposta também se aproximava do que Lacan, a partir da topologia, afirmara: "O sujeito está, se nos permitem dizê-lo, em exclusão interna a seu objeto" (cf. Lacan [1966] 1998:875). Afirmação que desloca o sujeito do lugar de quem, de fora, toma posse da língua, fazendo dela um de seus atributos ou pertences.

Caberia, então, elaborar o modo como essas três posições se articulariamm uma à outra em diferentes momentos da cronologia do processo. Pretendia-se, assim, atingir o objetivo maior de explicar as mudanças de posição a partir do efeito do funcionamento da língua, funcionamento esse que, do ponto de vista da criança enquanto nele inserida, não seria_repito_apreendido pela descrição de seus enunciados, e sim pelos processos metafóricos e metónímicos (cf. Jakobson 1963, de Lemos 1992, 1996).

Supondo-se que eles regeriam a relação dos enunciados da criança com o enunciado do outro na primeira posição, as relações entre enunciados na segunda posição e as relações entre fala e escuta na terceira posição, tornou-se importante não 
só mostrar sua natureza fundante quanto distinguir seus efeitos relativamente às posições.

\section{SOBRE A PRIMEIRA POSIÇÃO}

De início, é preciso dizer que a proposta apresentada acima significava, no meu trabalho, a passagem de uma visão diacrônica para uma visão estrutural ou, lembrando Saussure, sincrônica. Essa passagem não podia deixar de mobilizar uma série de reelaborações na concepção de língua, de sujeito e de outro, ou melhor, daquele que tem o estatuto de outro para a criança.

No que concerne à primeira posição, isso significa, a despeito do caráter fragmentado dos enunciados cronologicamente iniciais e de sua dependência da fala/interpretação do outro, que fragmentação e dependência não implicam um "antes da língua" nem uma assimilação do tipo reprodutivo relativamente aos enunciados do outro. Isto é, há desde sempre uma língua em funcionamento, o que determinaria um processo de subjetivação, o qual, por sua vez, impede que se pense em termos de uma coincidência entre a fala da criança e a do outro.

Dos episódios dialógicos analisados e reanalisados nesse momento, foi possível depreender pelo menos dois tipos de sequências representativas da primeira posição. Será através da análise de episódios representativos desses dois tipos que se poderá apontar para o funcionamento da estrutura na primeira posição:

Episódio 3 ( Criança entrega para mãe uma revista tipo Veja)

C.: ó nenê/o auau

M.: Auau? Vamo achá o auau? Ó, a moça tá tomando banho.

C.: ava? eva?

M: É. Tá lavando o cabelo. Acho que essa revista não tem auau nenhum.

C.: auau

Só tem moça, carro, telefone.

C.: Alô?

M.: Alô, quem fala? É a Mariana?

(Mariana $1 ; 2.15$ )

Episódio 5. (Criança se aproxima da televisão, mãe tenta afastá-la)

C.: não/não/ PO(entre pô e bô)

M.: Quebrô sim.

C.: a PO

M.: É, vai por, você não sabe por.

C.: a PO.

M.: O Pô vem aqui amanhã. Amanhã o Pô com a Titê para levá a Mariana na praia.

C.: iáia/iáia

M.: Ai que gostoso que a Titê vai chegar, né, filhinha? 


\section{C.: igá/ eva baldinho móia? \\ M.: Ahm? \\ C.: eva baldinho móia?}

M.: Leva? Ah, você vai levar o baldinho na praia? Vai sim, filha. Vai levar o baldinho na praia. Vai levá o caminhãozinho. Que é que você vai por dentro do baldinho?

\section{C.: aga.}

(Mariana 1; 8.6)

No primeiro tipo, representado pelo Episódio 3, cabe chamar a atenção não só para o retorno na fala da criança de parte dos enunciados usados pela mãe na situação de "ler revistas" com ela, que marca a dominância do pólo do outro na primeira posição ou, do ponto de vista da psicanálise, sua alienação na fala do outro.

O enunciado ó nenê/ o auau permite ir além da semelhança que o vincula a fala da mãe, em situações anteriores. Como foi antes apontado, depreende-se dos enunciados subsequentes da mãe que não há nem "nenê" nem "auau" na revista e que, nesse sentido, o que retorna da fala da mãe na fala da criança são significantes cujo significado não deixam de ser uma interrogação. Ainda que se possa interpretá-los como uma espécie de senha para pedir para a mãe "ler revista", sua relevância está, na verdade, no fato de sua opacidade apontar para a não-coincidência entre a fala da mãe e a fala da criança,. Isto é, para a separação enquanto contraparte da alienação, separação essa que permite falar em um sujeito que se faz presente nesse significar algo que, a despeito (e por causa) de sua opacidade, é outra coisa.

Para que essa não-coincidência se faça ver como efeito da língua, basta que se atente para outros enunciados que se seguem no episódio: a relação entre tomando banho na fala da mãe e ava na fala da criança, a relação entre telefone na fala da mãe e alô na fala da criança. Essas relações mostram mais que a mera dependência da criança relativamente à fala da mãe, ou, inversamente, como e quanto a coesão e a progressão do diálogo estão ancoradas na fala/interpretação da mãe.

O que interessa agora, do ponto de vista estrutural, é a escuta da fala da mãe que se revela na fala da criança. É um fragmento que ela recorta_telefone_o qual evoca alô, isto é, o texto de outra brincadeira familiar, "falar ao telefone". Não se trata mais de uma referência externa, como no caso precedente, isto é, de uma referência a uma situação interativa, "contextual". Trata-se de uma relação entre significantes, cuja referência é interna e que, ao mesmo tempo em que aponta para um funcionamento lingüístico, faz emergir dessa relação um sujeito. Se o pólo dominante ou convergente da primeira posição é o outro, as relações entre os significantes que vêm do outro dão a ver o funcionamento da língua e um processo de subjetivação por ele regido, isto é, que aponta para um sujeito emergente no intervalo entre os significantes do outro. .

O episódio 5 permite caracterizar esse segundo tipo de instanciação da primeira posição, em primeiro lugar, pela maior extensão e complexidade dos fragmentos que migram da fala da mãe para a fala da criança. É o caso de eva baldinho móia, convocado pelo vocábulo "praia", presente em enunciado precedente da mãe. Note-se que, apesar de ser um enunciado cujas "elipses" sugerem uma colagem de fragmentos, 
essa fala da criança governa, pelo menos em parte, a progressão do diálogo. Todo o diálogo, com efeito, e. em particular, a resistência inicial da criança à interpretação da mãe, mostra-a submetida menos à fala imediata da mãe do que aos significantes ausentes que eles convocam.

\section{SOBRE A SEGUNDA POSIÇÃO}

Pode-se dizer, preliminarmente, que o "êrro" é a característica da segunda posição e que foi a partir do contraste entre o "êrro" e o "acerto" que começou a delinear-se para mim a proposta sobre as três posições.

Contudo, nesse momento em particular, detive-me na substuição de um têrmo por outro em uma determinada posição, interessada menos no "êrro" que poderia advir da substituição, e mais em como essa se manifestava em sequiências paralelísticas. Interêsse que teve origem, em primeiro lugar, na interpretação a elas dadas por Lier- De Vitto (1998[1995]) no que se refere aos monólogos da criança. Em segundo lugar, pela sua presença insistente no jogo simbólico monológico, na relação da fala da criança com a fala da mãe na narrativa e em seqüencias de enunciados narrativos da criança.

Como se pode inferir tanto da estrutura paralelística em si quanto do tipo de atividade discursiva em que ela comparece_ uma atividade cujo efeito referencial é interno e em que a relação empírica imediata com o outro é secundária à relação com o texto _ esses fenômenos pareciam confirmar não só a língua como pólo dominante da segunda posição como uma vigência do processo metafórico para além do "êrro". Lembro aqui a insistência enfática com que Jakobson (1973) definia as sequiências paralelísticas na poesia, como uma projeção do eixo metafórico sobre o eixo metonímico.

Episódios como os que se seguem ilustram vários tipos de paralelismo:

Episódio 6: (desenhando um avião)

ó o avião que a Cuca vai comprá chapéu pra mim

ó o avião que o Michel vai comprá chapéu pra Cuca

ó o avião que a Cuca vai comprá chapéu pro Michel vai comprá casinha pra nós morá

(Michel 2;7.15)

Episódio 7: (brincando com uma boneca)

eu falo tudo que eu quero

ela come tudo que eu quero

ela faz tudo que eu quero

ela brinca que eu quero

ela brinca que eu faço

(Mariana 2;9. 28) 
Episódio 8:(Contando a estória do Pinóquio)

R.: ói quem segou da escola

Quem é?

é o grilo falante

o...o, como é que sama?

Pinóquio.

o...pinóquio

ó quem secou da escola

o pi-nó-quio!( com ênfase)

óia lá

Hum hum.

quem segou da escola?

o pi-nó-quio!

Hum hum.

ó aqui. Pinóquio sega da es-co-la

como é que sama?

Qual?

esse

O João Pilantra

João Pilanta segou até lá

da escola...então...

Hum

foi estevendo, escrevendo

estevendo, estevendo

estevendo, escrevendo

(R. bate ritmadamente no livro enquanto fala)

Foi escrevendo, e depois?

esse?

(não identifica o personagem como o mesmo da ilustração anterior)

É o João Pilantra também.

Zoão Pilanta foi esquevendo

e foi(SI)

Vamo, vamo virá?

Onde é que eles foram?

Então...

foi São Paulo

e foi São Paulo

São Paulo(baixo)

(R. 2.2.20) 
Episódio 9:( M. contando história para F.)

M.: Olha o Bábar passeando todo feliz com a mãe!

F.: O Bába chorando todo feliz no colo da mãe.

(F. 2;11.3)

$\mathrm{O}$ que se pode acrescentar ou reformular relativamente ao outro na segunda posição a partir da relevância e ampliação dos processos metafóricos no paralelismo? Em primeiro lugar, note-se que, relativamente à primeira posição, a criança, enquanto sujeito falante, não emerge apenas na relação entre a sua fala e a fala do outro, mas no intervalo entre os significantes que metaforicamente se substituem tanto no erro quanto nas sequiências paralelísticas.

Em segundo lugar, em contraste com a primeira posição em que o fragmento que comparece na fala da criança é como que um vestígio metonímico das cadeias pelas quais o outro a interpreta, na segunda posição, seus enunciados são cadeias permeáveis a outras cadeias e, portanto, passíveis de deslocamento, de ressignificação, de abrir-se para significar outra coisa.

Contudo, não operam, nem no erro nem na seqüência paralelística, restrições que incidam seja sobre a intromissão das cadeias latentes na cadeia manifesta _ veja-se ela brinca que eu faço_ nem sobre as cadeias que se sucedem, impedindo a progressão do diálogo e do texto narrativo_ veja-se a narrativa do Episódio 8.

Nesta altura, poder-se-ia perguntar sobre o sujeito que fala na segunda posição: alienado no próprio movimento da língua, o que ele escuta do que fala?

\section{SOBRE A TERCEIRA POSIÇÃO}

Do ponto de vista fenomênico, a terceira posição seria inicialmente caracterizável pela maior homogeneidade da fala da criança, pelo que, na proposta chomskiana, seria uma aproximação a um estado estável de conhecimento, ou pela aparente coincidência da fala da criança com a fala do adulto ou de sua comunidade.

Acrescente-se a isso o fato de que, concomitantes a essa estabilidade e/ou suposto grau de conhecimento, comparecem fenômenos como pausas, reformulações, correções convocadas ou não pela reação direta ou indireta do interlocutor. Enfim, todos os fenômenos que têm sido interpretados como relevando de uma capacidade metalingüística, isto é, de um conhecimento sobre o próprio conhecimento, na literatura psicolingüística sobre o assunto (cf., entre outros, Karmiloff-Smith 1986).

O episódio abaixo me permitirá apresentar uma interpretação alternativa e congruente com o que chamei de terceira posição.

Episódio 10: (Uma amiga(T.) da mãe da criança(V.) traçou no chão os quadros para ela e a V. brincarem de amarelinha, menos um)

V.: Quase que você não fez a amarelinha.

T.: O que, Verrô?

V.: Faz tempo que você não fez a amarelinha sua. 


\section{T.: O que, Verrô? Eu não entendi.}

V.: Está faltando quadro na amarelinha sua.

(Verônica 4; 0.8)

Note-se que, apesar de identificar onde/qual a expressão que, no seu enunciado, provocou um estranhamento em sua interlocutora, V. só conseguirá chegar a um enunciado correto ao substituí-la pela segunda vez. Por outro lado, o vínculo semântico entre a expressão a substituir e as que sucessivamente a substituem_ "algo que esteve para suceder, algo que já sucedeu, algo que deve suceder e não sucedeu”_ aponta claramente para os mesmo processos metafóricos vigentes na segunda posição e instanciados no erro e nas seqüências paralelísticas.

O que justifica tratar esse episódio como representativo da terceira posição não é, portanto, a correção efetuada pela criança, mas o efeito de diferenciação das expressões que se apresenta como a outra face do efeito de semelhança que as vincula, ou melhor, enquanto avesso do processo metafórico. Esse avesso aponta para uma mudança de posição na estrutura, isto é, para a emergência de um sujeito em outro intervalo: naquele que se abre entre entre a instância que fala e a instância que escuta, instâncias não coincidentes, como se mostra também no episódio que se segue:

Episódio 11: (Ao contar uma história, R. tenta, como diria o lingüista, colocar em discurso direto a fala de um personagem)

R.: Eu e a Aninha quando crescerem que nem (pausa longa) (retomando)João falou assim: eu e a Aninha quando crescê, crescerem...crescererem...querem sê almirante de navio.

(Raquel 4; 2.3)

Esse episódio mostra, com efeito, tanto pela retomada da expressão que introduz o discurso direto, quanto pelas sucessivas substituições da forma verbal crescerem, o reconhecimento pela criança da discrepância entre o que diz e o que deve dizer, ainda que não chegue à forma correta. Classificar esses enunciados como evidência de capacidade metalingüística equivaleria, com efeito, a camuflar o hiato entre essa fala que insiste no êrro e a escuta que reconhece esse erro.

Outro sinal importante da impossibilidade de pensar esses fenômenos como evidência de conhecimento é o fato de que, no que concerne à terceira posição, eles são o espaço em que se manifesta a heterogeneidade. Ou melhor, pausas, reformulações e correções não ocorrem sempre onde se faria necessário e podem ocorrer quando não parecem necessários, não sendo, portanto, previsíveis, como a noção de metaconhecimento, ou mesmo monitoração da fala, o exigiria.

Essa ênfase no erro e em sua correção na literatura sobre capacidade metalingüística, ênfase esta que advém da concepção da linguagem como objeto de conhecimento, tem servido para obscurecer outros fenômenos que relevam, na terceira posição, da escuta pela criança de própria fala, do reconhecimento do efeito que a substituição pode ter para a própria criança e para seu interlocutor. O episódio que se 
segue representa o reconhecimento pela criança do efeito irônico de uma simples substituição sobre toda a situação interativa:

Episódio 12: (Em meio a um longo sermão da mãe, dirigido à criança (R.) e a sua irmã (D.) sobre não comer fora das refeições)

D.: E iogurte, não pode comê iogurte fora das refeições?

V.: E porta, pode comê porta fora das refeições?( rindo)

(Raquel 4; 3. 5)

\section{PARA ALÉM DAS POSIÇÕES}

O sentido que possa ter a forma com que, até aqui, fui alinhavando e desalinhavando minha trajetória pela Aquisição de Linguagem, se detém agora diante de algo que, de repente, põe a perder o sentido, pondo em cena um outro, inesperado.

Refiro-me a um texto mais ou menos recente (cf. de Lemos 2000) onde, a partir da discussão de Saussure sobre a sincronia como a perspectiva do falante em relação à língua, introduzo mais argumentos contra a noção de desenvolvimento vigente na área de Aquisição de Linguagem e apresento minha proposta sobre as três posições para o leitor de uma revista americana de Psicologia ${ }^{17}$

Ao "ilustrar" a segunda posição com um episódio descrito por Bellugi e já referido e discutido por M.T. Lemos (1994: 80):

(ii) "In the middle of a session, Adam would open his eyes wide and provide me with special dialogues. In one case, Adam just

claimed he had a watch, but he never in fact had one, and what's more, couldn't tell time.

Me: 'I thought you said you had a watch.'

Adam: 'I do have one.(with offended dignity) 'What do you

think I am, a no boy with no watch?'

Me: 'What kind of a boy?'

Adam:(Enuntiating very clearly)' A no boy with no watch.'

(Bellugi 1982: 55)

surpreendo-me com o que, pela primeira vez, pude "escutar" da fala daquela criança. A saber: que, para além de ter-se valido de estruturas como nobody, nothing e no one, da sua língua, nelas irrompendo com o seu no boy, o que Adam estava "querendo dizer" a Ursula Bellugi e a "si mesmo" era que ele não era uma menina.

É significativo que, nesse mesmo artigo, ao expor o que vinha chamando de visão estrutural da mudança, introduzo no que antes era o pólo do sujeito ou da criança, a expressão corpo pulsional, expressão essa a que M.T. Lemos se refere, a partir da Psicanálise, ao comentar a metáfora do corpo em Pêcheux( 1982):

\footnotetext{
${ }^{17}$ Trata-se de um número especial da revista, organizado por C. Lightfoot e M.C. Lira.
} 
"Mas o corpo evocado por Pêcheux não é o corpo instintual, sistema de funções biológicas. É, antes, o corpo pulsional, superfície de pontos sensíveis, lugar de gozo e de recalque.[...]

A diferença entre o corpo biológico da urgência e o corpo pulsional se dá precisamente pelo fato de que num caso há a suposição de algo independente da linguagem e que constitui uma realidade última do homem[...], enquanto no outro o real do corpo está articulado na e pela linguagem.” (M.T. Lemos, op.cit.:25)

No lugar da criança referida como organismo_corpo biológico sob a égide da necessidade _ passo a colocar, portanto, o corpo pulsional, qualificado, no artigo referido, como o "que demanda interpretação", isto é, corpo que, "articulado na e pela linguagem", se acha no regime da demanda e do desejo.

Os efeitos desse deslocamento em minha posição de investigador (intérprete ou interpretado pela fala da criança?) se fazem sentir hoje no meu reconhecimento de que, embora reine o imprevisível e, portanto o singular na fala da criança, há zonas privilegiadas de "erros", de réplicas, de dispersões. O gênero é uma delas, como mostram o trabalho recente de Rosa Attié Figueira (2002) e o de Maria Fausta Pereira de Castro (2002). Seria, aliás desse ponto de vista que eu interpretaria hoje o enunciado A Fávia é nananda, referido no Episódio 2.

Uma outra zona é a dos pronomes pessoais (cf. de Lemos 1992b), das flexões verbais (cf. Figueira 2000), do discurso direto e indireto (cf. de Lemos 1992 e 2002), zona que, segundo Jakobson (1963 [1957]: 178), se define como "a parte do código que se refere à mensagem", isto é, ao chamado ato de enunciação. Enunciação cujo sujeito, segundo Lacan, não coincide com o sujeito do enunciado (Lacan 1961-1962).

Essas duas zonas de turbulência exigem que se trate da subjetivação implicada na trajetória da criança na/pela língua também do ponto de vista da sexuação. A travessia pelo complexo ou drama edipiano deixa suas marcas nessa trajetória, tanto no que da sexuação resiste no gênero gramatical quanto no que, da relação com o casal parental, é encenado pela "parte do código que se refere à mensagem".

O que chamei de terceira posição também foi afetado pelo reconhecimento de que o que acontece na fala da criança revela muito mais sobre a subjetivação do que sobre a língua. A escuta de sua própria fala, assim como a escuta da fala do outro em sua diferença, adviriam, então, não de um movimento da língua sobre si mesma_ de sua reflexividade_, mas do grande Outro, definido por Lacan (1998[1966]) como tesouro de significantes, do qual o emissor recebe sua própria mensagem invertida. $\mathrm{Ou}$, em outras palavras, onde a mensagem repercute e de onde retorna uma resposta divergente, uma resposta outra.

Dada essa mudança de minha posição como investigadora, o que, na verdade, restaria das três posições? É cedo para dizer, mas vislumbro um caminho que passa pela chamada patologia da linguagem e pela psicopatologia infantil, isto é, por um voltar-se para aquelas crianças que ou sucumbiram ou se enredaram em sua trajetória.

Um tal caminho está representado em meu trabalho atual por uma reflexão sobre duas classes de fenômenos. Primeiro, por aqueles que, semelhantes do ponto de vista da estrutura lingüística, se dão a ver tanto na fala da criança quanto nas patologias de linguagem e nas psicopatologias. 
É o caso do paralelismo(cf. de Lemos, a sair), que se faz presente tanto na poesia (Jakobson 1973[1966]) quanto nos ritos de cura chamânica (cf. Lévi-Strauss 1974[1958]), tanto na fala da criança quanto nos dizeres psicóticos (cf. Novaes 1996) e na fala do afásico ( Fonseca \& Lier-de Vitto, a sair). A extensão do paralelismo impõe que se indague sobre o que significa o fato de estruturas semelhantes produzirem efeitos tão díspares.

Esse também é o caso do processo de especularidade o qual, conforme Arantes (2000), "embora estruturante de uma posição na linguagem, indica um aprisionamento à fala do outro. Deve-se dizer, então, que um mesmo processo pode produzir efeitos diferentes - no caso, o patológico."

De outro lado, situam-se as diferenças, a saber, como a fala do autista_ quando há fala_se apresenta em contraste com a fala da criança, dessa criança generalizada pela pesquisa em aquisição de linguagem.

Esse contraste se faz ver, à primeira vista, entre os fragmentos da fala da mãe que retornam, enquanto significantes na fala da criança, e o que comparece na fala do autista como holófrase, isto é, enquanto bloco não desmembrável, carente de intervalos, impedindo substituições e deslocamentos relevantes. É o caso de Vitor que “ Sistematicamente, tenta completar séries introduzidas a partir de algum disparador: (T)..Casa? (V.) Apartamento, quatro quartos, segurança total, Avenida Francisco Morato de Oliveira, São Paulo, capital" (Vorcaro, 1999 :45).

Foi disso que me dei conta através do trabalho de Ângela Vorcaro ( 1999) e dos episódios clínicos em que a ecolalia insiste na fala de uma criança com provável diagnóstico de autismo na dissertação de mestrado de Mariana Trenche de Oliveira (2001). Contraponto a esse contraponto é o livro de Maria Francisca Lier-de Vitto (1998[1994]) sobre os monólogos da criança no berço, em que se flagra a criança fragmentando a fala do adulto que a capturou, desfazendo-a para delimitar seu lugar nela.

Na dissertação de Trenche de Oliveira, defrontamos-nos também com enunciados de uma criança em que comparecem em bloco numa voz e prosódia característica do apresentador da televisão, blocos intactos de comerciais como Mappin, nosso Mappin, em contraste com murmúrios e sussuros que apontam para o canto em que se aloja uma subjetividade abortada.

Um novo caminho se vislumbra e o que ele mostra é simplesmente que desfazer e refazer são operações que talvez digam mais das vicissitudes do investigador na investigação do que da matéria ou do sujeito supostamente investigado.

\section{REFERÊNCIAS BIBLIOGRÁFICAS}

ANDERSON, J. (1971). The Grammar of Case: Towards a Localistic Theory. Londres: Cambridge University Press.

ANDRADE, L. (1998). The status of linguistic data in language assessment procedures. Comunicação apresentada em painel na Sixth International Pragmatics Conference, Rheims, França. A sair em: M.F. Lier-de Vitto (org.) Sobre Aquisição, Patologias e Clínica de Linguagem. 
(2000) Os efeitos da fala como acontecimento na clínica fonoaudiológica. Comunicação apresentada no Sexto ENAL( a sair em Letras de Hoje)

ARANTES, L. (2000). As múltiplas faces da especularidade. Texto apresentado no I Encontro Internacional de Aquisição de Linguagem e V Encontro nacional de Aquisição de Linguagem, PURGS, Porto Alegre e a ser publicado.

. (2001). Diagnósticos e Clínicas de Linguagem. Tese de doutorado (inédita). LAEL-PUCSP.

ATKINSON, M. \& GRIFFITHS, P. (1973). Here's here's, there's here and there. EWPL 3 (29-73)

ATKINSON, M. (1974). Pre-requisites for reference. Trabalho apresentado no Seminário da BAAL, Universidade de Newcastle-upon-Tyne.

BALDWIN, J.M. (1899). Interprétation sociale et morale des principes de développement mentale. Paris: Alcan.

BELLUGI, U. (1982). The acquisition of a spatial language. Em T. Kessel (org.) The development of language and language researchers: Essays in honour of Roger Brown. Londres: Erlbaum.

BOWERMAN, M. (1982). Reorganizational processes in lexical and syntactic development. In E. Wanner \& L.R. Gleitman (Eds.), Language Acquisition: The State of the Art. Cambridge: CUP (142-78).

BROWN, R. \& BELLUGI, U. (1971[1964]). Three Processes in the Child's Acquisition of Syntax. Em A. Bar Adon \& W.F. Leopold(orgs.) Child Language: A Book of Readings. Englewood Cliffs: New Jersey: Prentice-Hall (307-318).

BRUNER, J. (1975). The Ontogenesis of Speech Acts. J.Ch. Lang. 2 (1-19).

CAMAIONI, L., GERBINO, W., STEFANI. L. (1978). L'interazione sociale tra bambini coetanei e tra bambini e adulto. Giornale Italiano di Psicologia IV-2 (291-321)

CARVALHO, G. (1995). Erro de pessoa: levantamento de questões sobre o equívoco em Aquisição de Linguagem. Tese de doutorado(inédita). DL-IEL-UNICAMP.

. (2000). Children's errors and the problematic status of recognition of communicative intentions. Comunicação apresentada em painel na Seventh International Pragmatics Conference, Budapest, Hungria.

. (a sair). O êrro em Aquisição da linguagem: um impasse. Em M.F. Lier-de Vitto (org. ) Aquisição, Patologia e Clínica de Linguagem.

CHOMSKY, N. (1959). Review of Skinner, Verbal Behavior. Language 35 (26-58). . (1965). Aspects of the Theory of Syntax. Cambridge, Mass. The MIT Press. . (1971[1964]). Formal discussion of Miller's and Ervin's The Development of Grammar in Child Language. Em A. Bar-Adon \& W. Leopold (orgs.) Child Language: A Book of Readings (340-343). . (1986). Knowledge of Language: its nature, origin and use. New York: Praeger. . (1995). The Minimalist Program. Cambridge, Mass.: The MIT Press.

CLARK, H.H. (1973). Space, time, semantics and the child. Em T.E. Moore (org.) Cognitive Development and the Acquisition of Language. Nova York: Academic Press (28-64).

CLARK, R. (1974a). Performing without competence. Journal of Child Language 1 (1-10)I (1977). What's the use of imitation? Journal of Child Language 4 (341-358)

DOWTY, D.R. (1972). Studies in the logic of aspect and time reference in English. Tese de doutorado. Austin: Universidade do Texas. 
FARIA, N.R.B. ( 2001) A difícil aritmética do corpo e da linguagem: reflexões sobre o input e a aquisição de linguagem. Tese de doutorado (inédita). Programa de Pós-Graduação em Lingüística, UFAL.

FIGUEIRA, R.A. (1984). The development of causativity expressions : a syntactic hypothesis. Journal of Child Language11-1 (109-127).

(2000). L'acquisition du paradigme verbal du portugais. Les multiples directions des faute. Calap 20 (45-64).

(2002). Marcas Insólitas na Aquisição de Gênero. Trabalho apresentado em mesa-redonda no XIII Congresso Internacional da ALFAL. A sair em Lingüística.

FONSECA, S.C. (1995). Afasia: a fala em sofrimento. Dissertação de mestrado(inédita). LAEL-PUCSP.

FONSECA, S. \& LIER-DE VITTO (no prelo). Lingüística, Aquisição de Linguagem e Patologia: Relações possíveis e restrições obrigatórias. Anais do V Encontro Nacional sobre Aquisição de Linguagem: outubro 2000.

FREUD,S. (1976[1900]). The Interpretation of Dreams. Harmondsworth: Penguin Books.

GRIFFITHS. P. (1974). That there deixis I. Trabalho apresentado em Seminário na Universidade de Edimburgo.

GRUBER, J. (1967). Topicalization in Child Language. Foundations of Language 3 (37-65).

JAKOBSON, R. (1963[1956]). Deux aspects du langage et deux types d'aphasie. Em Essais de Linguistique Générale. Paris: Minuit.

(1963[1960). Linguistique et Poétique. Em Essais de Linguistique Générale (209-248).

(1973). Le paralléllisme grammatical et ses aspects russes. Questions de Poétique. Paris: Seuil( 234-279).

LACAN, J. (1988[1973]). O Seminário- Livro 11: Os Quatro Conceitos Fundamentais da Psicanálise. Rio de Janeiro: Zahar.

(1961-1962). Séminaire IX: L’Identification. Publicação interna da Associação Freudiana, Paris. . (1998[1966]). Escritos. Rio de Janeiro: Zahar.

DE LEMOS, C.T.G. ([1975] 1987). Ser and estar in Brazilian Portuguese with particular reference to child language acquisition. Tübingen: Gunter Narr Verlag.

. (1981). Interactional processes in the child's construction of language. In W. Deustch (Ed.) The

Child's Construction of Language. Cambridge: CUP (57-76).

. (1982). Sobre Aquisição de Linguagem: e seu Dilema(Pecado) Original. Boletim da ABRALIN 3 (97-136).

(1985). Specularity as a constitutive process in dialogue and language acquisition. Em L. Camaioni \& C. de Lemos (orgs.) Questions on Social Explanation: Piagetian Themes Reconsidered. Amsterdam: John Benjamins (23-31).

. (1991). Saber a língua e o saber da língua. Aula inaugural do ano letivo de 1991. Campinas: Setor de Publicações do IEL, UNICAMP.

. (1992a). Los procesos metafóricos y metonímicos como mecanismos de cambio. Substratum 1 (121-136)

(1992b) From dialogue processes nad narrative perspectives. Em M.S.Z. de Paschoal e M.A. Cellani (orgs.) Lingüística Aplicada: da aplicação da Lingüística à Lingüística transdisciplinar. São Paulo: EDUC (83-98).

. (1995a). Da morte de Saussure o que se comemora? Psicanálise e Universidade 3 (41-52).

(1995b). Língua e discurso na teorização sobre aquisição de linguagem. Letras de Hoje 102 (9-29).

(1997). Native speaker's intuitions and metalinguistic abilities: what do they have in common from the point of view of language acquisition? Cadernos de Estudos Lingüísticos 33 (5-14).

. (1998a). Interrelações entre a Lingüística e outras ciências. Boletim da ABRALIN 22 (19-31). 
. (1998b). Interrelações entre a Lingüística e outras ciências. Boletim da ABRALIN 22 (19-31).

(1999). A criança $\operatorname{com}(0)$ ponto de interrogação. Em Regina Lamprecht(org.) Aquisição de

Linguagem:Questões e Análises. Porto Alegre: EDIPUCRS (39-50).

. (2000). Questioning the notion of development: the case of language acquisition. Culture \&

Psychology 6(2) (169-182).

. (no prelo). Sobre fragmentos e holófrases. Anais do Encontro organizado pelo LEPSI-USP.

. (a sair). O paralelismo, sua extensão e a disparidade de seus efeitos. Em M.F.Lier-de Vitto (org.)

Sobre Aquisição, Patologias e Clínica de Linguagem.

- (a sair). Sobre o estatuto lingüístico discursivo da narratva na fala da criança. Trabalho apresentado em mesa redonda do XIII Congresso Internacional da ALFAL. A sair em Lingüística.

. (a sair). Corpo e Corpus. Trabalho apresentado na I Jornada Corpo e Linguagem e a ser publicado em coletânea em preparação.

LEMOS, M.T. (1994) A língua que me falta: uma análise dos estudos de aquisição de linguagem.Tese de doutorado inédita, IEL-UNICAMP. A sair: Campinas: Mercado de Letras.

LÉVI-STRAUSS, C. (1974[1958]). Anthropologie Structurale I. Paris: Plon.

LIER-DE VITTO, M.F. ([1995] 1998). Os Monólogos da criança: delírios da Língua. São Paulo: EDUCFAPESP.

(1997). (org.) Fonoaudiologia: no sentido da linguagem. São Paulo: Cortez.

- (2002) A confluência língua-discurso nos monólogos da criança. Trabalho apresentado em mesa redonda no XIII Congresso Internacional da ALFAL. A ser publicado em Lingüística.

LYONS, J. (1975). Deixis as a source of reference. Em E. Keenan (org.) Formal Semantics of Natural Languages. Londres: Cambridge University Press (61-83).

MILNER, J.-Cl. (1989). Introduction à une Science du Langage. Paris: Seuil. (2002). Le périple structural: figures et paradigme. Paris: Seuil.

NOVAES, M. (1996). Os Dizeres nas Esquizofrenias: Uma cartola sem fundo. São Paulo: Escuta.

OLIVEIRA, M.T. (2001). Ecolalia-Quem fala nessa voz? Dissertação de mestrado inédita. LAEL-PUCSP.

PECHEUX. M. (1982). Sur la (dé)construction des théories linguistiques. DRLAV 27 (1-24).

PEREIRA DE CASTRO. M.F. (1992 [1985]). Aprendendo a argumentar: Um momento do processo de aquisição de linguagem. Campinas: Editora da UNICAMP.

(2002). A argumentação na fala da criança: entre fatos da língua e de discurso. Trabalho apresentado em mesa-predonda do XIII Congresso Internacional da ALFAL. A sair em Lingüística.

PERRONI, M.C. (1983/1992). Desenvolvimento do discurso narrativo. São Paulo: Martins Fontes.

PETERS, A. (1983). The units of language acquisition. New York: Cambridge University Press.

PIAGET, J. (1928). Logique génétique et sociologie. Revue Philosophique 53,3/4 (167-205).

PINKER, S. (1987). The bootstrapping problem in language acquisition. Em B. MacWhinney (org.) Mechanisms of Language Acquisition. Hillsdale, N.J.: Lawrence Erlbaum.

- (1989) Learnability and cognition: The acquisition of argument structure. Cambridge, Mass.: The MIT Press.

. (1995). The Language Instinct. Londres: Penguin Books.

RADFORD, A. (1990). Syntactic Theory and the Acquisition of English Syntax: The Nature of Early Child Grammars in English. Oxford: Blackwell. 
SAUSSURE, F. de (1916/1972). Cours de Linguistique Générale. Édition critique préparée par Tullio de Mauro. Première édition, 1916. Paris: Payot.

SILVEIRA, E. (2000). Embaraço. Texto inédito.

SCARPA, E.M. (1984). The development of intonation and dialogue processe in two Brazilian children. Tese de doutorado inédita. SOAS, Universidade de Londres.

SNOW, C. (1972). Mothers' speech to children learning language. Child Development 43 (549-65).

VERAS, V. (2000). A inter-dicção do singular. Cadernos de Estudos Lingüísticos.

VORCARO, A. (1999). Crianças na Psicanálise: clínica, instituição e laço social. Rio de Janeiro: Companhia de Freud .

WALLON, H. (1949). Les origines du caractère chez l'enfant. Paris: PUF.

VYGOTSKI, L. ([1930]1978). Mind in Society: The development of Higher Psychogical Functions.. Cambridge, Mass.: Harvard University Press. 